pathogenesis of experimental murine cerebral malaria. J Immunol 1996;15:1620-1624.

23. Chimelli L, Mahler-Araujo MB. Fungal infections. Brain Pathol 1997;7:613-627.

24. Graninger W, Prada J, Neifer S, Zotter G, Thalhammer F, Kremsner P. Upregulation of ICAM-1 by Plasmodium falciparum: in vitro and in vivo studies. J Clin Pathol 1994;47:653-655.

25. Jakobsen P, Morris-Jones S, Ronn A, et al. Increased plasma concentrations of sICAM-1, sVCAM-1 and sELAM-1 in patients with Plasmodium falciparum or P. vivax malaria and association with disease severity. Immunol 1994;83:655-659.

26. Jander S, Heidenreich F, Stoll G. Serum and CSF levels of soluble intercellular adhesion molecule-1 (ICAM-1) in inflammatory neurologic diseases. Neurology 1993;43:1809-1813.

27. Wenisch C, Parschalk B, Burgmann H, Looareesuwan S,
Graninger W. Decreased serum levels of TGF-beta in patients with acute Plasmodium falciparum malaria. J Clin Immunol 1995; 15:69-73.

28. Flanders KC, Ren RF, Lippa CF. Transforming growth factorbetas in neurodegenerative disease. Prog Neurobiol 1998;54: 71-85.

29. Brown H, Turner G, Rogerson S, et al. Cytokine expression in the brain in human cerebral malaria. J Infect Dis 1999;180: $1762-1746$.

30. Yong VW, Krekoski CA, Forsyth PA, Bell R, Edwards DR. Matrix metalloproteinases and diseases of the CNS. Trends Neurosci 1998;21:75-80.

31. Paul R, Lorenzi S, Koedel U, et al. Matrix metalloproteinases contribute to the blood-brain barrier disruption during bacterial meningitis. Ann Neurol 1998;44:592-600.

\title{
Neuro/mages
}
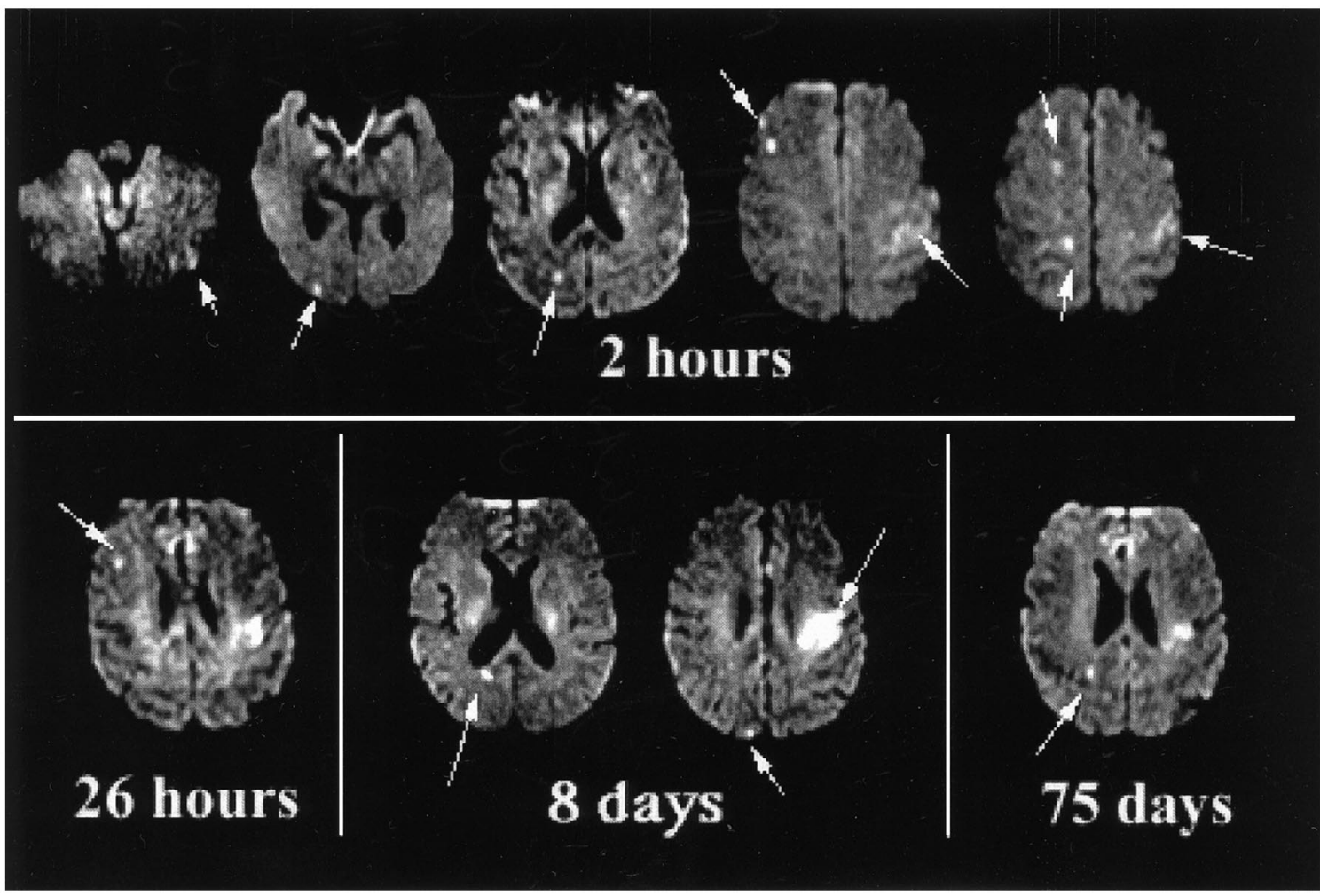

Figure. Diffusion-weighted MRI study. Arrows indicate areas of acute ischemic injury.

\section{Recurrent silent cerebral embolism}

\section{A.E. Baird, FRACP, PhD, S. Warach, MD, PhD, Bethesda, MD}

Multiple silent cerebral ischemic lesions in space and time occurred in a 58-year-old man with an untreated left ventricular cardiac thrombus. ${ }^{1-2}$ This patient initially presented with a sudden onset of expressive dysphasia, rightsided weakness and hypotension, with a history of myocardial infarction and poor left ventricular function. The first MR diffusion-weighted imaging (DWI) study was obtained two hours after the onset of symptoms. The hyperintense areas (arrows) indicate acute ischemic injury. DWI lesions were present in the left frontal region, the right cerebral hemisphere, and the left cerebellar hemisphere. On serial MR studies new clinically silent small lesions were detected. At 26 hours and 8 days new lesions had developed in the right cerebral hemisphere (arrows). The left frontal lesion had shown some signs of lesion evolution with hyperintensity and some enlargement. At 75 days a new lesion was present adjacent to the posterior horn of the right lateral ventricle. An apical thrombus was subsequently found on transesophageal echocardiography. A previous bleeding episode had precluded anticoagulation until this time.

1. Baird AE, Lovblad KO, Schlaug G, Edelman RR, Warach S. Multiple acute stroke syndrome. Marker of embolic disease? Neurology 2000;54:674-678.

2. Babikian VL, Caplan LR. Brain embolism is a dynamic process with variable characteristics. Neurology 2000;54:797-801. 


\title{
Neurology
}

\author{
Recurrent silent cerebral embolism \\ Neurology 2000;55;111 \\ DOI 10.1212/WNL.55.1.111
}

This information is current as of July 12, 2000

\section{Updated Information \&} Services

Permissions \& Licensing

Reprints including high resolution figures, can be found at: http://n.neurology.org/content/55/1/111.full

Information about reproducing this article in parts (figures,tables) or in its entirety can be found online at:

http://www.neurology.org/about/about_the_journal\#permissions

Information about ordering reprints can be found online:

http://n.neurology.org/subscribers/advertise

Neurology ${ }^{\circledR}$ is the official journal of the American Academy of Neurology. Published continuously since 1951, it is now a weekly with 48 issues per year. Copyright . All rights reserved. Print ISSN: 0028-3878. Online ISSN: 1526-632X.

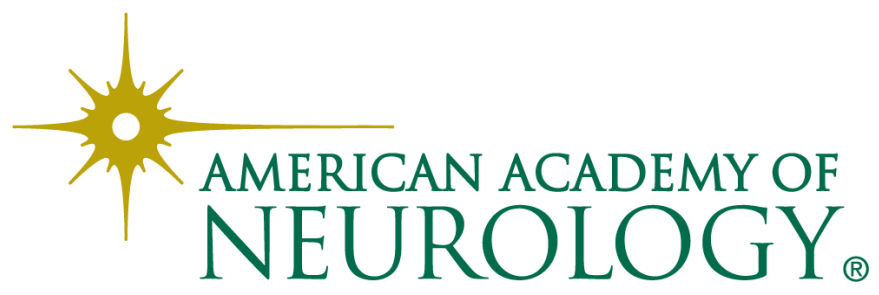

